\title{
FRANCUSKO-AUSTRIACKIE STOSUNKI POLITYCZNE OD BITWY POD MARENGO DO TRAKTATU POKOJOWEGO W LUNÉVILLE
}

Streszczenie. Po kampanii 1797 r. i podpisaniu pokoju w Campo Formio, Austria poniosła straty terytorialne. Utraciła przede wszystkim lewy brzeg Renu, północne Włochy i Belgię. W 1798 r. car Paweł zdecydował się włączyć do konfliktu. Dało to nadzieję Anglii i Austrii. Rozpoczęła się walka Francji i jej sprzymierzeńców z II koalicją. Po licznych zwycięstwach wrogów Republiki, oszukany przez sojuszników car Paweł, zdecydował się zmienić stronę konfliktu. Bitwa pod Marengo (14 czerwca 1800 r.) odwróciła sytuację. Austria poniosła klęskę militarną i trzeba było zmusić ją do podpisania pokoju kontynentalnego. Anglia wsparła Wiedeń subsydiami w wysokości 2,5 mln funtów, ale postawiła warunek. Rząd austriacki nie mógł podpisać osobnego pokoju z Francją do lutego $1801 \mathrm{r}$. Wysłany do Paryża Saint-Julien podpisał preliminaria, chociaż nie miał pełnomocnictw. Podtrzymanie zawieszenia broni kosztowało Austrię Inglostadt, Ulm i Philippsburg. Formalne rozmowy pomiędzy Józefem Bonaparte i Cobenzlem zaczęły się w październiku. Ich wynikiem był pokój podpisany w Lunéville 9 lutego 1801 r., który kończył walki na kontynencie.

Słowa kluczowe: Napoleon, Francja, polityka zagraniczna, Bonaparte, Marengo, Lunéville.

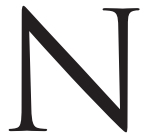

iniejszy tekst jest w dużej mierze oparty na mojej pracy licencjackiej, obronionej w 2018 r. w Instytucie Historii. Jej celem było udowodnienie trwałości i potencjału systemu europejskiego, opartego na polityce Republiki Francuskiej po 1799 r. i Lidze Północnej. Wybrałem z niej wątek relacji politycznych między Francją i Austrią których bezpośrednim następstwem był pokój zawarty w Lunéville 9 lutego 1801 r. Stanowił istotny element polityki rządu francuskiego, którego celem było zaprowadzenie pokoju powszechnego w Europie. Dzięki traktatowi zawartemu z Austrią udało się doprowadzić do zakończenia walk na kontynencie. Celem mojej 
pracy jest przede wszystkim zobrazowanie dziejów konfliktu austriacko-francuskiego, ukazanie roli i problematyki północnych Włoch w wojnach tego okresu oraz systemie zależności politycznych, jakie kierowały dyplomacją austriacką. Starałem się przede wszystkim skupić się na dyplomacji a nie na charakterystyce konfliktu militarnego.

Historiografia polskojęzyczna nie oferuje szczegółowych opracowań, dotyczących polityki zagranicznej tego okresu. Najdokładniejszą pracą, jaką się posłużyłem jest Historia Konsulatu i Cesarstwa Adolphe'a Thiersa ${ }^{1}$, którą to zakwalifikowałem w swojej bibliografii jako źródło ze względu na warsztat autora. Wiemy, że pisząc swoje wielotomowe dzieło, miał on okazje rozmawiać bezpośrednio z uczestnikami, opisywanych przezeń wydarzeń. Ponadto, opisując historię mu współczesną, był równocześnie zaangażowany w politykę. Drugą pracą, którą uważam za dość szczegółową, jest biografia Napoleona Bonaparte autorstwa Alberta Manfreda², w której autor zawiera dość szczegółowe opisy wydarzeń. 0 wiele szerszy dostęp do informacji oferuje francuska historiografia. W swojej pracy skorzystałem z dzieł pisanych jeszcze w XIX w., a więc z Histoire de France depuis le 18 brumairejusqu'a la paix de Tilsitt barona Louisa Pierre'a Bignona ${ }^{3}$, l'Europe et la révolutionfrançaise Alberta Sorela ${ }^{4}$, czy Histoire de la politique des puissances de l'Europe $e^{5}$. Ta ostatnia nie odnosi się jednak tylko do Francji. Wątek polityki rosyjskiej wobec Sardynii oraz Austrii podczas drugiej i pierwszej koalicji porusza w swoich studiach ${ }^{6}$, ambasador honorowy włoski, książę Giuseppe Greppi. Wśród polskich źródeł wydanych, kwestie polityczne tego okresu najszerzej opisuje książę Adam Jerzy Czartoryski w swoich pamiętnikach ${ }^{7}$. Najważniejszym źródłem dla mnie była przede wszystkim francuska ${ }^{8}$ oraz rosyjska ${ }^{9}$ korespondencja dyplomatyczna.

${ }^{1}$ A. Thiers, Historia Konsulatu i Cesarstwa, t. 1, Oświęcim 2013-2014.

2 A. Manfred, Napoleon Bonaparte, t. 1, Warszawa 1986.

${ }^{3}$ Histoire de France, depuis le 18 brumaire (novembre 1799) jusqu'a la paix de Tilsitt (juillet 1807), par M. Bignon, t. 1, Paris 1829.

${ }^{4}$ A. Sorel, l'Europe et la révolutionfrançaise, Paris 1903.

${ }^{5}$ Histoire de la politique des puissances de l'Europe, depuis le commencement de la Révolution Française jusqu'a congrès de Vienne; par M. le Comte de Paoli-Chagny, t. 1, Paris 1817.

${ }^{6}$ G. Greppi, Sardigne, Autriche-Russie pendant la première et la duxième coalition (17961802), Rome 1910.

7 A.J. Czartoryski, Pamiętniki i memoriały polityczne 1776-1809, oprac. J. Skowronek, Warszawa 1986.

${ }^{8}$ Correspondance de Napoléon I ${ }^{\text {er }}$, t. 6-7, Paris 1860-1861; Correspondance de Talleyrand avec le Premier Consul pendant la campagne de Marengo, publiée par Le $C^{\text {te }}$ Boulay de la Meurthe, bmw. 1892 oraz Lettres inédites de Talleyrand a Napoléon 1800-1809 publiées d'après les orginaux conservés aux archives des Affaires étrangères avec une introduction et des notes par Pierre Bertrand, Paris 1889.

9 Sbornik Imperatorskogo Russkogo Istoriczeskogo Obszczestwa, t. 1, wyd. A.S. Traczewski, Sankt Petersburg 1890. 
Wydarzenia lat 1799-1801 były następstwem wojen prowadzonych przez rewolucyjną Francją i ich nieodłącznym elementem. Rozpoczęte w 1792 r. zmagania Republiki z Austrią zakończyły się pięć lat później pokojem zawartym w Campo Formio ${ }^{10}$. Na mocy traktatu, cesarz odstąpić miał Republice Belgię i lewy brzeg Renu, zaś na terenie Lombardii uznano zależną od Francji Republikę Cisalpińską. Austria otrzymywała Wenecję z Istrią, ponadto Dalmację z wyspami. Nabytki francuskie w Niemczech miało rekompensować biskupstwo salzburskie ${ }^{11}$.

Obecny w Wiedniu ambasador rosyjski, hrabia Andriej Razumowski, w dniu podpisania pokoju, nie został poinformowany o jego warunkach co wywołało oburzenie w Petersburgu. Car postanowił jednak aktywniej włączyć się w walkę z Francją z dwóch powodów: po pierwsze - dążył do uprawomocnienia swojego panowania na Malcie, której to ogłosił się władcą, jako Wielki Mistrz Zakonu; po drugie - czuł się zbawcą Europy i dążył do zaprowadzenia w niej sprawiedliwości. Chociaż powątpiewano w intencje Razumowskiego na wiedeńskim dworze, miał on nadal pełnić funkcję ambasadora. Jego rola jednak miała wzrosnąć wobec zmiany kursu polityki ${ }^{12}$.

Włączenie się na szerszą skalę Petersburga do konfliktu ogólnoeuropejskiego dawało nadzieję Austrii i Anglii. Należy pamiętać, że dotychczas Rosja nie angażowała swoich wojsk na większą skalę na terenie zachodniej Europy. Uważana za jedną z najlepszych armii na kontynencie, miała wkrótce uderzyć na tereny Północnych Włoch i Szwajcarii.

Działania te zbiegły się z rozszerzeniem horyzontu działań militarnych również Republiki. Dyrektoriat zaaprobował plan generała Bonaparte dotyczący inwazji na Egipt ${ }^{13}$, mającej być ciosem wymierzonym przede wszystkim w handel pomiędzy Anglią i Indiami ${ }^{14}$. Ofensywa była na tyle poważnie traktowana przez Londyn, że w 1799 r. Anglicy zdobyli Aden - port, kontrolujący przepływ z Morza Czerwonego do Zatoki Adeńskiej i Morza Arabskiego ${ }^{15}$. Mimo początkowych zwycięstw latem 1798 r., syryjska inwazja wojsk francuskich zakończyła się niepowodzeniem.

1017 października 1797 r.; właściwie pokój był zawarty w Passariano.

11 M. Kukiel, Dzieje polityczne Europy od rewolucji francuskiej, Londyn 1992, s. 127.

12 M. Razumovsky, Razumowscy. Rodzina na carskim dworze, Warszawa 2005, s. 217-219.

13 T. Łepkowski, Napoleon a daleki świat, [w:] Europa i świat w epoce napoleońskiej, red. M. Senkowska-Gluck, Warszawa 1977, s. 414-417.

${ }^{14}$ Takie państwa, jak np. Rosja kupowała towary kolonialne za pośrednictwem Anglii, Holandii czy Danii po cenie droższej, niż jakby sprowadzała je bezpośrednio. Dla Anglików był to bardzo duży zysk, zaś zajęcie Egiptu mogło zaburzyć istniejący system ekonomiczny; patrz: Dwie zapiski na temat Indii, [w:] Archiw kniazia Woroncowa, t. 24, Moskwa 1880, s. $186-187$.

15 T. Wituch, Kanał Sueski, Warszawa 1972, s. 20-24. 
Wobec klęsk wojsk Republiki na kontynencie, Bonaparte w sierpniu 1799 r. opuścił Egipt. Koalicja utworzona przez Anglię, Austrię, Rosję Królestwo Neapolu i Turcję poważnie zagrażała egzystencji systemu politycznego, utworzonego przez republikańską Francję ostatnimi laty.

Pod koniec 1798 r. rosyjski korpus ekspedycyjny w sile 27 tysięcy żołnierzy pod dowództwem generała Rosenberga przekroczył granice Galicji. Szybko doszło do licznych nieporozumień między sztabem rosyjskim a władzą austriacką. Aprowizacja zawodziła, a zakwaterowanie nie odpowiadało oczekiwaniom, przez co dochodziły nieustanne skargi do Petersburga na Razumowskiego. Listem z 14 stycznia 1799 r. car odwołał swojego ambasadora, mianując na jego miejsce Stiepana Kołyczewa, jednak po interwencji dworu i wysunięciu propozycji objęcia dowodzenia przez Aleksandra Suworowa, zmienił zdanie ${ }^{16}$. Razumowski pozostał w Wiedniu, a 15 kwietnia 1799 r. dowództwo nad wojskiem austriacko-rosyjskim przejął Suworow, jeden z najsławniejszych dowódców końca XVIII stulecia. Jego gwiazda miała jednak zgasnąć niemal równocześnie z gwiazdami Desaix’a, Klébera i Jouberta. Z tym ostatnim rosyjski generalissimus miał się zmierzyć. Od wiosny wojska francuskie ponosiły klęskę za klęską. W dniach 26-28 kwietnia generał Moreau został pobity nad rzeką Addą, dzień później padł Mediolan. Wkroczenie Suworowa do stolicy Lombardii było równoznaczne z utratą najważniejszych zdobyczy generała Bonaparte i diametralnie pogorszyło sytuację i tak już kompromitującego się Dyrektoriatu. Końcem maja padł Turyn, w czerwcu wojska francuskie, dowodzone przez generała Étienne’a Macdonalda poniosły klęskę nad Trebbią. 6 lipca Francuzi, do których docierały te fatalne wieści, skierowali swój wzrok na młodego generała Barthelemy’ego Jouberta. W prasie ukazała się bowiem informacja, obwieszczająca przejęcie przezeń dowództwa nad armią francuską we Włoszech ${ }^{17}$.

Joubert nie miał pełnić funkcji jedynie wojskowej - niektóre kręgi polityczne Paryża widziały w nim przyszłe narzędzie do obalenia ówczesnego rządu i stworzenia z jego pomocą nowej formy rządów. Inicjatorem był jeden z najważniejszych aktorów sceny politycznej - Emmanuel-Joseph Sieyès. Należy mieć bowiem na uwadze, że w pierwotnym założeniu okazja obalenia Dyrektoriatu przypaść miała generałom Moreau lub Joubertowi. Dzień 15 sierpnia przekreślił jednak tę koncepcję. Niedaleko miejscowości Novi, w starciu wojsk francuskich z armią koalicji, dowodzoną przez owianego już legendą Suworowa, generał Joubert poległ w pierwszej fazie bitwy.

\footnotetext{
16 M. Razumovsky, op. cit., s. 219-220.

17 A. Manfred, op. cit., s. 244-245.
} 
Latem 1799 r. nie tylko z Włoch nadchodziły tragiczne wieści. Dowodzący wojskiem angielsko-rosyjskim książę Yorku wylądował w Holandii, stwarzając zagrożenie dla Francji na kolejnym froncie. Rząd Republiki Batawskiej opowiedział się po stronie koalicji ${ }^{18}$. Celem armii było przekroczenie Belgii i uderzenie od strony Flandrii w kierunku Paryża. Sytuację w Batawii uratował jednak generał Guillaume Brune, który 19 września pod Bergen pokonał wojska koalicji.

Austriacy popełnili błąd, który w niedalekiej przyszłości miał przynieść fatalne skutki. Dążyli bowiem do odniesienia zwycięstwa przy pomocy i poświęceniu wojsk rosyjskich. Celem miało być wyparcie Francuzów ze Szwajcarii. Według planu, wojska Suworowa miały przebić się przez Alpy i uderzyć od południa, Aleksandr Rimski-Korsakow nacierać miał od północy, zaś główny trzon armii austriackiej pod dowództwem arcyksięcia Karola, zamiast stanowić zabezpieczenie dla wojsk rosyjskich, wycofał się do pasywnej postawy. Między 25 a 26 września, dowodzący w Szwajcarii generał André Masséna zadał klęskę wojskom rosyjskim pod Zurychem. Nie miała ona jednak znaczenia jedynie militarnego ${ }^{19}$. Car, dowiedziawszy się o sytuacji, w jakiej zostały postawione wojska rosyjskie, poczuł się zdradzony przez dotychczasowych sojuszników. W październiku pisał do cesarza Franciszka I:

\section{Szanowny Bracie!}

Wasza wysokość z pewnością zna już skutki, które nastąpiły przez oddalenie ze Szwajcarii pańskiej armii pod dowództwem arcyksięcia Karola; ten ruch był sprzeczny z wszystkimi pobudkami, przez które ta armia musiała pozostać aż do połączenia się marszałka księcia Italisky'ego z generałem Rimsky'm-Korsakowem. Widząc moje oddziały opuszczone i poświęcone za cenę polityki absolutnie sprzecznej wobec mnie i Europy, i mając wszelkie powody do bycia niezadowolonym z zachowania pańskiego ministra $[\ldots]^{20}$.

Posunięcie okazało się fatalne w skutkach. Bez wojsk rosyjskich koalicja nie mogła stawić czoła wojskom francuskim na kontynencie. Sam król Anglii pisał do cara z wyrozumiałością i krytycznie odnosił się do polityki Wiednia, prosząc równocześnie o pozostanie w sojuszu i wsparcie w wielkim „dziele restauracji Europy"21.

18 Ibidem, s. 246.

19 J. Baszkiewicz, Historia Francji, Wrocław 1978, s. 465.

20 G. Greppi, op. cit. s. 92 - list cara Pawła do cesarza Franciszka, pisany z Gatczyny dnia 22/11 października 1799 r.

21 Ibidem, s. 93. 
Po objęciu urzędu, jednym z pierwszych posunięć Bonapartego na polu polityki zagranicznej było wystosowanie listów do króla Anglii Jerzego III i cesarza niemieckiego Franciszka ${ }^{22}$. W obu korespondencjach Pierwszy Konsul proponował pokój i zaprzestanie rozlewu krwi. Oczywistym jednak było, że niemożliwy jest on do osiągnięcia, ponieważ ani Francja nie odstąpi swoich zdobyczy, ani państwa koalicji nie ustąpią. Korespondencja była jedynie zręcznym manewrem politycznym, usprawiedliwiającym działania Bonapartego. Wiedział, jak bardzo pokój był pożądany we Francji i całej Europie, więc posunięcie to miało skuteczny wydźwięk propagandowy. Sam nie mógł nic zrobić, i choć doskonale zdawał sobie sprawę z odpowiedzi, jaką otrzyma, zagrał pozorami ${ }^{23}$.

Z Londynu nadeszła obelżywa odpowiedź Williama Pitta ${ }^{24}$. Nawiązywała do grabieży i napaści na terenie Niemiec, Szwajcarii, Holandii i Włoch, sugerowała, że warunkiem pokoju byłaby restauracja Burbonów, gwarantująca bezpieczeństwo i porządek w Europie. Replikę zaadresowano do Williama Grenville'a. Usprawiedliwiała ona postępowania Francji, jako wojnę obronną oraz sprytnie odniosła sugestię restauracji Burbonów do przywrócenia na tron angielski Stuartów. Ponownie naciskano na rozpoczęcie rokowań pokojowych. Grenville, pozostający pod silnym wpływem Pitta, gorącego zwolennika wojny, ponownie odmówił ${ }^{25}$. Zdaje się, jakby replika francuska była niepełna ${ }^{26}$. Niefortunnie działania francuskie usprawiedliwiano wojną obronną; nie nawiązano zupełnie do świeżych gwałtów floty brytyjskiej, skierowanych przeciwko okrętom państw neutralnych, które to gwałty budziły tak wielki sprzeciw na arenie międzynarodowej. Bezsprzecznie łamane było prawo międzynarodowe, uznane przez przygniatającą większość państw europejskich. Zamieszczenie uwag na ten temat w nocie adresowanej do Grenville'a nie tylko neutralizowałoby angielskie argumenty, ale zbliżałoby Francję do państw neutralnych, wliczając w nie oczywiście Prusy i Rosję, o relację z którymi Pierwszy Konsul usilnie się starał.

${ }^{22}$ Do króla Anglii, [w:] Correspondance de Napoleon I Ir, $n^{\circ} 4445$, t. 6, s. 46; Do cesarza - $n^{\circ}$ 4446, [w:] Ibidem, s. 47: „Obcym jest mi poczucie próżnej chwały, zaś pierwszym z moich pragnień jest zatrzymać rozlew krwi. Wszystko wskazuje, że w następnej kampanii armie liczne i zręcznie dowodzone potroją liczbę ofiar [...]" czytano w Wiedniu (tłum. własne); oba listy zostały wysłane 25 grudnia $1799 \mathrm{r}$.

${ }^{23}$ Ch. Talleyrand, Pamiętniki, tłum. W. Dłuski, Londyn 1994, s. 173; A. Manfred, op. cit., s. 332.

${ }^{24}$ Nota napisana przez lorda Grenville'a, zaadresowana do Talleyranda, Bonaparte pisał wcześniej wprost do króla Wielkiej Brytanii.

${ }^{25}$ A. Thiers, op. cit., t. I/1, s. 113-114.

${ }^{26}$ Correspondance de Napoleon $I^{e r} n^{o} 4530$, t. 6, s. 117. 
Odpowiedź z Wiednia napisana była w podobnej formie, sygnowana została przez ministra spraw zagranicznych Austrii, Franza Marię Thuguta ${ }^{27}$. Respons Bonapartego został przekazany najpierw Talleyrandowi, następnie skierowany do Wiednia ${ }^{28}$.

Szans na pokój nie było. Bonaparte przystąpił do działań. Skupił je na najbliższym wrogu, a więc Austrii, której wojska zajmowały północne Włochy i dopiero zostały odparte ze Szwajcarii. W tym celu nawiązano kontakty dyplomatyczne z Turcją i Prusami. Pierwsza z prób zakończyła się niepowodzeniem w wyniku kapitulacji wojsk francuskich pod Al-Arisz. Misja, na którą udał się Geraud Duroc do Berlina, dawała zaś nadzieje ${ }^{29}$. Bonaparte chciał się posłużyć Prusami nie tylko w celu zbudowania politycznej presji na Austrii, ale również widział w nich szansę stworzenia przeciwwagi w stosunku do Rosji ${ }^{30}$.

Polityka Pawła wobec Francji od 1799 r. ulegała powolnym zmianom. Wojska rosyjskie, nie otrzymawszy pomocy ze strony ze strony Austrii nie odnosiły oczekiwanych zwycięstw. Jak już zostało wspomniane, Paweł uznał się za oszukanego przez swoich sojuszników i wycofał wojska z Zachodniej Europy, odstępując równocześnie od koalicji ${ }^{31}$. Pierwszy konsul konsekwentnie budował relację z Rosją, wykorzystując błędy austriackiej dyplomacji ${ }^{32}$. Tak silny wschodni sojusznik mógł być niezwykle skutecznym odciążeniem dla Republiki na froncie austriackim.

Przygotowania Francji do konfrontacji zbrojnej trwały już od początku grudnia 1799 r.; pierwszy konsul zdawał sobie doskonale sprawę z tego, że rozstrzygnięcie będzie konieczne na polu bitwy. Tworzenie armii rezerwowej było zręcznym manewrem ze strony Bonapartego; prowadzone było w ścisłej tajemnicy, miała ona być zaskoczeniem nie tylko dla Austriaków, ale dla całej Europy, bacznie obserwującej północną Italię i zachodnią granicę

27 Odpowiedź dotarła 15 stycznia.

${ }^{28}$ Correspondance de Napoleon $I^{e r} n^{0} 4623$, t. 6, s. 192.

29 J. Tulard, Napoleon - mit zbawcy, Warszawa 2003, s. 151.

${ }^{30}$ Correspondance de Napoleon $I^{e r} n^{0} 4542$, t. 6, s. 129.

31 L. Bazylow, Historia Rosji, t. 1, Warszawa 1983, s. 357.; Ch. Talleyrand, op. cit., s. 173.

32 „Panie hrabio, pierwszy konsul Republiki Francuskiej wiedział o wszystkich okolicznościach kampanii, która poprzedzała jego powrót do Europy. Wie o tym, że Anglicy i Austriacy zawdzięczają wszystkie swoje zwycięstwa współdziałaniu wojsk rosyjskich, i jako że on szanuje męstwo, jako że przede wszystkim stara się wyrazić swój szacunek dla dzielnych wojsk, pospieszył nakazać, aby komisarzom, którym polecone było przez Anglię i Austrię wymienić jeńców, zaproponowano włączyć w tę wymianę także Rosjan, znajdujących się we Francji, a nawet wyświadczyć im niektóre udogodnienia, jako, że są mniej przyzwyczajeni do tego klimatu i przebywanie w tym kraju mogło być dla nich szkodliwe". Talleyrand do hrabiego Panina, 20 lipca/1 thermidora z Paryża, [w:] Sbornik Imperatorskogo..., s. 1-3 (tłum. własne). 
Niemiec. Do wojny przygotowywane były dwie armie francuskie - generała Moreau w liczbie 100 tys. żołnierzy w okolicach Renu, oraz „rezerwowa”, licząca 60 tys. żołnierzy, przeznaczonych do niespodziewanego przebicia się przez Alpy i walk w północnych Włoszech, dowodzonych przez pierwszego konsula ${ }^{33}$.

25 kwietnia Moreau przekroczył Ren. Sukcesy przyszły szybko, bowiem już 3 maja Claude Jacques Lecourbe zwyciężył pod Stokach, zaś Gouvion Saint-Cyr pod Engen. Dwa dni później Moreau pokonał generała Pála Kraya pod Moesskirch. Po serii zwycięstw otrzymał rozkaz oddzielenia 15 tys. żołnierzy ze swoich szeregów i odesłania ich w stronę Italii. Następnie 9 maja Saint-Cyr znowu odniósł zwycięstwo pod Biberach, zaś 10 maja Lecourbe odrzucił Austriaków w okolicach Vorarlbergu na Ulm, torując sobie drogę na południe do Genewy. Przybywszy 13 maja do Lozanny, pierwszy konsul dzień później wydał rozkaz wymarszu armii rezerwowej na odsiecz broniącemu się w Genui André Massenie. Nie wytrzymał jednak on w mieście i musiał skapitulować 4 czerwca - mimo ogromnego poświęcenia zarówno cywili, jak i żołnierzy francuskich. Armia, z którą nadciągał Bonaparte okazała się ogromnym zaskoczeniem. Chociaż nie dotarła przed poddaniem stolicy Ligurii, przemierzyła niezwykle ciężką drogę, prowadzącą przez Alpy, wyzwoliła Lombardię, restytuując Republikę Cisalpińską i pokonała wojska austriackie 14 czerwca w okolicach Marengo ${ }^{34}$.

Wiedeń, dotychczas odmawiający przyjęcia pomocy finansowej ze strony Anglii zmuszony został do podporządkowania się propozycjom Londynu. 20 czerwca/1 messidora zawarto układ, na mocy którego w zamian za subsydia w wysokości 2,5 miliona funtów szterlingów, Austria zobowiązała się do lutego 1801 r. nie zawierać z Francją pokoju. Wyjątkiem miał być traktat obejmujący również Wielką Brytanię ${ }^{35}$. Stawiało to dwór wiedeński w trudnej sytuacji, ponieważ po klęsce pod Marengo, ciągnięcie stanu wojny przez kolejne 8 miesięcy było rzeczą kłopotliwą. Zadaniem dyplomacji austriackiej było więc opóźnianie rozmów i gra na czas, który stał się jedynym, poza Anglią, sojusznikiem Austrii. Stosunki Francji z Austrią zaogniała sytuacja panująca w Republice Cisalpińskiej, gdzie stale walczyły jeszcze oddziały partyzanckie. 23 czerwca/4 messidora Bonaparte obłożył dodatkową kontrybucją wojenną okupantów ${ }^{36}$.

${ }^{33}$ A. Zahorski, op. cit., s. 91.

${ }_{34}$ A. Manfred, op. cit., s. 335-343; J.-P. Bertaud, Histoire du Consulat et de l'Empire. Chronologie commentée, Paryż 2004, s. 27-31.

35 A. Sorel, op. cit., s. 54-55; A. Thiers, op. cit., t. I/2, s. 12.

${ }^{36}$ Correspondance de Napoleon $I^{\text {er }} n^{\circ} 4945$, t. 6, s. 486. 
5 lipca/16 messidora Franciszek wysłał do Paryża generała majora hr. de Saint-Julien'a (nie uzbrajając go w żadne pełnomocnictwa), który wiózł list adresowany bezpośrednio do Pierwszego Konsula. Miał on się dowiedzieć o żądania zawarcia pokoju ze strony Francji ${ }^{37}$. Ponadto w liście zawarte były propozycje ze strony Wiednia; oczekiwano zrzeczenia się przez Francję dominacji nad Holandią, Szwajcarią, Piemontem oraz wycofania się z Republiki Cisalpińskiej i całych północnych Włoch ${ }^{38}$. Postulaty były nie do przyjecia. Ciężko jednoznacznie ocenić i wyjaśnić zachowanie cesarza. Rozważyć można kilka wariantów. Być może dwór wiedeński nie zdawał sobie sprawy z sytuacji nie tylko militarnej w północnej Italii, ale również politycznej, a więc z polepszających się relacji Paryża z Petersburgiem oraz aktywnie działających dyplomatów na pozostałych dworach państw europejskich. Prawdopodobnym wyjaśnieniem może być również, że Wiedeń szukał możliwości odbudowania armii po ofiarowaniu gigantycznych subsydiów brytyjskich i głęboko wierzył w realną szanse militarnego sukcesu. Sytuacja pokazuje, że nacisk wywierany przez Pawła na Wiedeń nie był silny, a równocześnie cesarz miał nadzieje na podźwignięcie Armii Italii, która stanowiła jedynie część ogólnego stanu. Na froncie niemieckim, mimo klęsk, armia austriacka pod dowództwem PálaKraya cały czas się broniła - klęska więc nie była przesądzona.

Podjęta już wcześniej polityka wobec sprzymierzonej, a równocześnie podporządkowanej Republiki Batawskiej dawała owoce i stanowiła realne wsparcie dla działań Francji. Decyzją Bonapartego szeregi armii francuskiej miały zostać wzmocnione przez oddziały batawskie. W tym celu skonsultował się on przez Talleyranda z Rutgerem Schimmelpenninckiem - reprezentantem rządu batawskiego w Paryżu. Posiłki holenderskie miały zostać oddane pod dowództwo generała Pierre'a Augereau ${ }^{39}$. Tego samego dnia Bonaparte pisał do ministra wojny, Carnota:

Jeśli dwór Wiednia jest chętny do układów pokojowych, będzie trzeba je zacząć przez generalne zawieszenie broni, ale życzę sobie je podpisać, gdy armia Batawii będzie w sercu Niemiec w celu prezentacji sił, by złamać długą i powolną drogę dworu Wiednia, i przynieść nie tylko rozsądny pokój, ale również szybkie jego zawarcie ${ }^{40}$.

${ }^{37}$ A. Manfred, op. cit., s. 380, również A. Thiers, op. cit., t. I/2, s. 12-13.

${ }^{38}$ A. Sorel, op. cit., s. 55-56.

39 Obwieszczenie z 3 lipca/14 messidora: „Celem oddziałów armii generała Augereau będzie zagrozić Czechom, zmusić Austrię opuszczenia swoich pozycji, wesprzeć lewą flankę armii Renu na tyle na ile to możliwe, i wreszcie zmusić wszystkich małych książąt Niemiec do zawarcia oddzielnych traktatów pokojowych po narzuceniu im kontrybucji", vide: Correspondance de Napoleon $I^{\text {er }}$, t. 6, n ${ }^{\circ}$ 4961, s. 495-496 (tłum. własne).

${ }^{40}$ Ibidem, n 4959, s. 494 (tłum. własne). 
Podstawowym zadaniem Armii Batawii było więc wywieranie stałej presji na dworze wiedeńskim poprzez militarne zagrożenie Czech oraz zmuszenie niemieckich petitsprinces do zawarcia odrębnych traktatów pokojowych. Bonaparte dopuścił możliwość oddalenia się gen. Augereau o 8 do 10 dni marszu od Renu, co oznacza przesunięcie piechoty do około $280 \mathrm{~km}$ na wschód od rzeki, a więc na samą granicę Czech. Miała być ona bowiem zdolna do ewentualnej konieczności obrony granic ${ }^{41}$.

Na terenie Batawii obawiano się kolejnego ataku ze strony Anglii, jednak sytuacja uspokajała się z końcem roku, kiedy to temperatura spadała a dzień stawał się coraz krótszy. Zbliżała się jesień. Bonaparte podkreślał w nadchodzącej kampanii rolę kilkutysięcznej holenderskiej armii generała Augereau, mimo jej niewielkiej liczebności. Po przekroczeniu przez generała Moreau Innu, korpus ten miał podejść aż pod Rednitz. Rozkaz został wydany 29 sierpnia/11 fructidora ${ }^{42}$.

Ustaliwszy preliminaria, hr. Saint-Julien wyruszył razem z upoważnionym przez pierwszego konsula Duroc'iem do Wiednia. Istniało jednak zagrożenie, z którego austriacki poseł doskonale zdawał sobie sprawę i informował o nim Talleyranda, mianowicie, że Duroc może napotkać trudności z przejazdem przez granicę. Tak też się stało; gdy francuski poseł dotarł 4 sierpnia/16 thermidora do kwatery głównej generała Kraya w Altötting, austriacki dowódca odmówił uposażenia go w paszport. Saint-Julien wyjechał więc do Wiednia sam, deklarując ubieganie się dla niego o niezbędne dokumenty. Gdy dotarł na miejsce, został zganiony przez cesarza oraz ukarany zesłaniem na prowincję. Nie dosyć, że nie miał żadnych pełnomocnictw, to jeszcze układając się z Francją, narażał relację angielsko-austriacką, a konkretniej finansowe wsparcie Londynu jakże niezbędne w tym czasie dla realizacji polityki Wiednia. Artykuły uznano za nieważne, a Duroc, czekający na dokumenty do 13 sierpnia (25 thermidora), powrócił do Paryża ${ }^{43}$.

Manfred zupełnie nie postrzega - w przeciwieństwie do Thiersa - działania Talleyranda jako błędu; wręcz przeciwnie, jego działanie nazywa mistrzowskim ${ }^{44}$. Sytuacja uległa zmianie po odpowiedzi ze strony cesarza, proponującego bezzwłoczne otwarcie kongresu pokojowego na terenie Francji, jednak z udziałem angielskiego pełnomocnika. W ten sposób udało się nie tylko uniknąć załamania finansowej polityki Londynu, ale również oddalić pokój ${ }^{45}$. Doprowadzając do sytuacji, w której przy jednym stole mie-

\footnotetext{
${ }^{41}$ Ibidem, $\mathrm{n}^{\circ}$ 4961, s. 495-496.

42 Ibidem, $\mathrm{n}^{\circ}$ 5077, s. 566-567.

43 A. Thiers, op. cit., t. I/2, s. 36.

${ }^{44}$ A. Manfred, op. cit., s. 380.

${ }^{45}$ A. Thiers, op. cit., t. I/2, s. 37.
} 
liby dyskutować przedstawiciele Francji i Anglii bez wątpienia dyplomacja austriacka zmniejszałaby szansę szybkiego zawarcia oczekiwanego traktatu. Gdyby Austria stała się jedynym partnerem formalnych i oficjalnych rozmów z Bonapartem, nie tylko musiałaby od początku iść na ustępstwa, ale również Anglia odstąpiłaby od sojuszu z słusznego powodu złamania umowy. Można więc przypuszczać, że Talleyrand nie mógł przewidzieć postawy dyplomacji angielskiej wobec posunięcia Saint-Juliena. Wejście z nim w układy okazało się błędem dopiero po odpowiedzi Thuguta z 11 sierpnia (23 thermidora).

Ostatecznie po powrocie francuskiego kuriera z Wiednia, obrano politykę wrogości. Pierwszy konsul na podstawie postawy rządu austriackiego wnioskował, że chce on zadać Francji klęskę zimą. Wydał polecenie Carnotowi, by ten przekazał austriackiemu sztabowi informacje wznowieniu działań wojennych ze strony Francji z powodu odrzucenia preliminariów podpisanych przez Saint-Juliena. Padła również propozycja przedłużenia zawieszenia broni o kolejny miesiąc pod warunkiem oddania Francji twierdz w Inglostadt, Ulm i Philippsburgu ${ }^{46}$.

Od czerwca w stałym interesie Wiednia była gra na czas i zyskanie go jak najwięcej. Wojska austriackie nie były przygotowane do podjęcia działań wojennych, dyplomacja ponosiła klęski, skarb był napełniany przez brytyjskie pieniądze. Ceną, jaką rząd austriacki był w stanie zapłacić za kolejne tygodnie zawieszenia broni, okazały się wspomniane twierdze: Philippsburg, Ulm i Inglostadt, z których dwie ostatnie leżały w dolinie Dunaju. Stanowiły one doskonałe podstawy dla działań Francuzów, opierając się o rzekę w pobliżu Monachium $^{47}$. Równocześnie Pierwszy Konsul zgodził się na udział angielskich pełnomocników w czasie planowanego w Lunéville kongresu - pod warunkiem jednak zatwierdzenia przez Wielką Brytanię traktatu morskiego.

W większości noty, wysłanej 4 vandemiaire'a ze strony pierwszego konsula do Thuguta, sprawującego jeszcze funkcję odpowiedzialnego za dyplomację Austrii, pierwszy konsul kładł nacisk na sprawy włoskie oraz bezpośrednio samych Włochów. Dopominał się o zwrócenie wolności obywatelom, jak Giovanni Battista Caprara ${ }^{48}$ czy Pietro Moscati. Ponadto

${ }^{46}$ Correspondance de Napoleon I ${ }^{e r}$, t. 6, $\mathrm{n}^{\circ}$ 5099, s. 580, gdzie w liście do Carnota czytamy: „Kurier, na którego czekano, powrócił z Wiednia; nie przynosi żadnej pozytywnej odpowiedzi. To dowodzi, że dwór w Wiedniu chce odnieść zwycięstwo zimą. Poinformuj generała austriackiego, że jest pan zobowiązany ponownie wystąpić z wrogością, ponieważ Jego Cesarska Mość odmówiła ratyfikacji preliminariów pokojowych, podpisanych w Paryżu przez P. księcia Sant-Juliena; że jeśli jednak on zgadza się na pańskie przejęcie bez zwłoki miejsc Inglostadt, Ulm i Philippsburg, zgadza się pan na przedłużenie zawieszenia broni w ciągu miesiąca" (tłum. własne).

${ }^{47}$ A. Thiers, op. cit., t. I/2, s. 42.

${ }^{48}$ Najpewniej chodzi o Giovanniego Battistę Caprarę, od 1792 r. kardynała, od 1800 r. biskupa Jesi, później na życzenie Pierwszego Konsula legat a latere w Paryżu, gdzie zjawił się 
zażądano od Wiednia ewakuacji wojsk austriackich z prawego brzegu Padu, co istotne - z wyjątkiem miasta i twierdzy Ferrary. W dalszej części - Bonaparte groził uderzeniem wojsk francuskich na południową część półwyspu w razie odmowy oddania papieżowi Ankony ${ }^{49}$. Dostrzec można w nocie wyraźne odwołania do całości Półwyspu: Lombardii, Toskanii, Neapolu i Rzymu, ale najistotniejszym ogniwem wydaje się być ten ostatni. Żądania wobec Austriaków w kwestiach terytorialnych i społecznych nie były niczym nowym ani nadzwyczajnym, jednak upomnienie się o zwolnienie z więzienia człowieka Kościoła oraz o ewakuację Ankony i oddanie papieżowi miasta miało poważniejsze znaczenie. Nie tylko godziło to w Austriaków, ale równocześnie ukazywało Francuzów w oczach Rzymu jako wartościowego partnera politycznego, a samego Pierwszego Konsula jako osobę zaufaną i przyjaźnie nastawioną - a przecież rozmowy dotyczące konkordatu niebawem miały nabrać tempa.

20 października/28 vendémiaire’a Józef Bonaparte otrzymał oficjalne instrukcje preliminaryjne na konferencję $\mathrm{w}$ Lunéville. W głównej mierze skupione były one wokół sposobu obradowania; Pierwszemu Konsulowi zależało bowiem na rozmowach między pełnomocnikiem Francji i Austrii wyłącznie. Równocześnie Bonaparte zażądał propozycji kontrprojektu traktatu pokojowego, skoro cesarz odrzucił preliminaria, zaproponowane przez gabinet Paryża i uzgodnione z Saint-Julienem. Francuska racja stanu pozostała przy poprzednim poglądzie; zażądano Flandrii, terytoriów belgijskich na lewym brzegu Renu, Sabaudii, Nicei, Bazylei etc ${ }^{50}$.

W Petersburgu po stronie koalicji powiększała się opozycja anglomanów przeciwna polityce, prowadzonej przez $\mathrm{cara}^{51}$. Osobą, która otwarcie występowała po stronie dworu wiedeńskiego był między innymi Nikita Panin. Jego projekty jednak oceniano negatywnie ${ }^{52}$.

Do Lunéville hrabia Cobenzl przybył 24 października. Ciężko jednoznacznie ocenić, nie mając dostępu do źródeł pisanych, jaki był cel rezygnacji z porozumienia z Francją. Albert Manfred. sugeruje, że decyzje mogły być motywowane nadchodzącymi $z$ różnych stolic europejskich informacji na temat bliskiego upadku Napoleona Bonaparte. Gdyby rzeczywiście ministerstwo spraw zagranicznych Austrii sugerowało się wątłymi przesłankami o prawdopodobnym upadku reżimu francuskiego, świadczyłoby to o kom-

w październiku 1801 r.; vide: Encyklopedia kościelna podług teologicznej encyklopedii Wetzera i Weltego, z licznemi jej dopełnieniami przy współpracownictwie kilkunastu duchownych i osób świeckich, oprac. X. Michał Nowodworski, t. 3, Warszawa 1974, s. 112-113.

${ }^{49}$ Correspondance de Napoleon $I^{\text {er }} n^{\circ}$ 5111, t. 6, s. 588.

50 Ibidem, $n^{\circ}$ 5131, s. 601.

${ }^{51}$ N. Ejdelman, op. cit., s. 208-214.

${ }^{52}$ A. Manfred, op. cit., s. 371-375. 
pletnym braku świadomości politycznej i wszelkiej rozwagi. Chociaż sugerowano zamach lub porwanie pierwszego konsula, trzeba spojrzeć nieco surowiej na planowane rozwiązania - zamiary i przypuszczenia nie mogły determinować działań politycznych zwłaszcza w obliczu tak dobrze prosperującego tworzonego przez Pierwszego Konsula systemu ${ }^{53}$.

Po przybyciu, hrabia Cobenzl otrzymał zaproszenie do Paryża, gdzie zjawił się 29 października/7 brumaire'a; Bonaparte chciał osobiście porozmawiać $\mathrm{z}$ austriackim dyplomatą; zawieszenie broni zostało przedłużone o kolejne 20 dni. Przedstawione żądania wobec Włoch lub posiadłości niemieckich w Szwabii, Bawarii albo Palatynacie, były jednak na tyle nieadekwatne do zaistniałej rzeczywistości politycznej, że pierwszy konsul pozwolił sobie na „żywe potraktowanie” austriackiego pełnomocnika tak, że ten zażądał powrotu do Lunéville, gdzie liczył na łatwiejszą i delikatniejszą rozmowę z Józefem. Do wymiany pełnomocnictw między nimi doszło 9 listopada. Już na samym początku w odpowiedzi na pytanie, czy rozmowy będą się toczyły bez udziału pełnomocnika angielskiego, Cobenzl odpowiedział, że w takim układzie nie wejdzie w rozmowy ${ }^{54}$. Józef był zobowiązany sukcesywnie informować pierwszego konsula o przebiegu rozmów ${ }^{55}$.

Drażliwą kwestią były zbuntowane jednostki w Toskanii, określane w korespondencji i historiografii jako levée en masse. Już bowiem 15 października Talleyrand otrzymał polecenie poinformowania brata cesarskiego, wielkiego księcia Toskanii, Ferdynanda ${ }{ }{ }^{56}$ o problemach z nimi związanych:

Przekaże mu Pan, że zbuntowane tłumy Toskanii urządzają częste burdy, że jest $\mathrm{w}$ intencji rządu francuskiego by szybko zostały zakończone; że generał Brune w konsekwencji napisał załączony list do generała komendanta w Toskanii w imieniu Jego Królewskiej Mości ${ }^{57}$.

Pozostający zgodnie z konwencją z Alessandrii w Toskanii z kilkoma setkami ludzi, generał Hannibal Sommariva, wspierał pieniędzmi angielskimi powstanie, działające na szkodę Francuzów. Zostało to odebrane przez stronę francuską jako zerwanie zawieszenia broni ${ }^{58}$. Bonaparte zdecydował się podjąć zdecydowane kroki. Murat dostał rozkaz przeniesienia się z okolic Amiens do Italii, generał Pierre-Antoine Dupont otrzymał rozkaz uderzenia na Toskanię z brygadami Pino, Malhera i Carra Saint-Cyra; szybko

${ }^{53}$ Correspondance de Napoleon $I^{e r}$, t. 6, n 5139, s. 607; A. Manfred, op. cit., s. 380-381 oraz A. Thiers, op. cit., s. 78.

${ }^{54}$ A. Thiers, op. cit., s. 78-79.

${ }^{55}$ Correspondance de Napoleon $I^{\text {er }}$, t. 6, $\mathrm{n}^{\circ}$ 5178, s. 640-641.

56 M. Żywczyński, Włochy nowożytne 1796-1945, Warszawa 1971, s. 70.

57 Correspondance de Napoleon I ${ }^{\text {r }, ~ t . ~ 6, ~ n ~}{ }^{\circ}$ 5127, s. 598-599 (tłum. własne).

${ }^{58}$ Clark do Bonapartego, z Brukseli 10 grudnia/19 frimaire'a, [w:] Sbornik Imperatorskogo..., s. 14-17. 
zajął Florencję, następnie rozbił zbiegłych buntowników w Arezzo, pacyfikując region. Wrogie działania buntowników w Toskanii były skoordynowane z ruchami wojsk neapolitańskich, austriackich i angielskich ${ }^{59}$.

Prawo do negocjowania organizacji Włoch i Niemiec rościł sobie również car, wyraźnie stając w obronie takich państw jak Sardynia, Królestwo Obojga Sycylii, Wirtembergia i Bawaria ${ }^{60}$.

Po interwencji francuskiej we Włoszech, Cobenzl, w pełnym zaufaniu, zgodził się na rozmowy niezależnie od angielskiego pełnomocnika. Do 1 lutego jednak miały one odbywać się nieoficjalnie i w ścisłej tajemnicy. W przypadku niepowodzenia rozmów, wszystkie papiery dyplomatyczne obu stron miałyby zostać zwrócone, a obecność pełnomocnika angielskiego miałaby pokryć jego udział. Cobenzl zażądał wstrzymania działań zbrojnych, na co pierwszy konsul się zgodził pod warunkiem podpisania pokoju w ciągu 48 godzin pod jasno określonymi warunkami. Ren miał stanowić granicę między Francją a Niemcami, Mantua miała zostać odstąpiona Republice Cisalpińskiej, przez co granicą między Austrią i Włochami miała stać się rzeka Mincio, zamiast opierać się na Adydze, w skład Republiki Cisalpińskiej należeć miały Lombardia, Valtellina, Parma i Modena; Toskania miała zostać oddana księciu Parmy, Legacje miały zostać oddane księciu Toskanii, a Piemont, Genua i Szwajcaria miały zostać niepodległymi państwami. Ze strony Austriaków były to zbyt duże ustępstwa i zbyt krótki czas na podjęcie takich decyzji. W związku z tym, zapowiedziane na 28 listopada działania wojenne, zostały wznowione. Francja była w pełni przygotowana do wojny ${ }^{61}$.

Do jednego z najważniejszych starć kampanii miało dojść już 5 dni po wznowieniu działań wojennych przez Francję, a więc 3 grudnia 1800 r. Moreau, dysponujący w swoim sztabie takimi dowódcami jak Michael Ney, czy Emmanuel de Grouchy oraz armią liczącą niecałe 60 tys. żołnierzy miał stawić czoła liczniejszej, bo siedemdziesięciotysięcznej armii pod dowództwem arcyksięcia Jana ${ }^{62}$. Batalia zakończyła się kolejną klęską wojsk austriackich i zwycięstwem do niedawna owianego legendą na równi niemal z Bonapartem, generała Moreau. Czekano jeszcze tylko na zwycięstwo w Italii, które odbierano już jako rzecz pewną. Pierwszy konsul był przekonany, że odniesione dwa zwycięstwa na kontynencie zmuszą Anglię do podpisania pokoju morskiego w ciągu najwyżej trzech miesięcy. Miał ku temu podstawy - wojska francuskie maszerowały przez Bawarię, w stronę Wiednia oraz ku Wene-

${ }^{59}$ A. Thiers, op. cit., s. 80.

${ }^{60}$ Nota hrabiego Rostopczyna, Gatczyna 26 września/8 października, [w:] Sbornik Imperatorskogo..., s. 10-11; o stosunku dyplomacji rosyjskiej do kwestii europejskich mówi również dość szczegółowo wspomniana nota Clarka do Bonapartego, patrz: przypis 59.

${ }^{61}$ A. Thiers, op. cit., s. 80-81.

${ }^{62}$ Ibidem, s. 90-95. 
cji na wschodzie, na zachodzie wspierała Francję sprzymierzona Hiszpania a pertraktacje z Rosją i innymi państwami przynosiły sukces za sukcesem. Wkrótce jednak admirał George Keith miał rozkaz wylądować w okolicach Ankony i Wenecji z siłą 15 tysięcy żołnierzy, jednak Bonaparte doskonale sobie zdawał sprawę, że car zamierza wypowiedzieć wojnę Anglii ${ }^{63}$. Czynnik ten był prawdopodobnie istotny w takim samym stopniu, jak kontynentalne klęski Austrii.

W Lunéville Cobenzl i Józef Bonaparte oczekiwali rezultatów toczących się walk w Niemczech i Włoszech. Coraz to nowsze wieści, dopływające z pól bitew, a przykre dla Austriaków, nie złamały dyplomaty austriackiego. Ze spokojnością okazywał on Józefowi pewność, że francuskie wojska, idące stale naprzód, napotkają w końcu silny opór. Nie rezygnował również z żadnego z żądań Austrii, miał odwagę nawet grozić zerwaniem rozmów i opuszczeniem Lunéville. Po klęsce pod Hohenlinden i zawarciu rozejmu w Steyr ${ }^{64}$, cesarz niemiecki polecił Cobenzlowi zawrzeć ze Republiką traktat. 31 grudnia oświadczył on stronie francuskiej gotowość do podpisania wstępnych warunków albo traktatu stanowczego. Przed odstąpieniem Austriaków od Anglii, miał zostać podpisany najpierw wspólny dla Włoch i Niemiec rozejm. Zgodnie z żądaniami dworu wiedeńskiego, granicą Austrii we Włoszech miała być rzeka Oglio, następnie Legacje. Książęta Modeny i Toskanii mieli zaś być przywróceni do dawnych posiadłości. Podstawą negocjacji był traktat zawarty trzy lata wcześniej, w CampoFormio. Różnicę stanowił fakt, że wynagrodzenia dla domu wiedeńskiego miały być wyznaczone nie w Niemczech, a we Włoszech ${ }^{65}$.

Myśli Pierwszego Konsula ustaliły się teraz. Chciał, aby Austria opłaciła koszty kampanii zimowej; chciał, żeby miała samą tylko Adygę, i utraciła w ten sposób wszelkie wynagrodzenie, bądź w Niemczech, bądź we Włoszech, za pomniejsze posiadłości odstąpione na lewym brzegu Renu. Co się tyczy Legacji, życzył je sobie zachować dla różnych planów. Dotychczas należały one do Republiki Cisalpińskiej. Zamyślał pozostawić je przy niej lub poświęcić na rozszerzenie domu parmeńskiego, obiecane traktatem dworu hiszpańskiemu. W tym ostatnim przypadku oddałby Parmę Republice Cisalpińskiej, a Toskanię domowi parmeńskiemu, co byłoby znacznym powiększeniem, a Legacje wielkiemu księciu Toskanii. Co się tyczy księcia Modeny, Austria przyrzekła traktatem z Campo Formio wynagrodzić go za utracone księstwo w postaci Bryzgowii. Do niej więc należało dotrzymać swoich zobowiązań względem tego księcia ${ }^{66}$.

${ }^{63}$ Correspondance de Napoleon $I^{\text {r }}$, t. 6, $\mathrm{n}^{\circ}$ 5211, s. 662-663.

${ }^{64}$ Co nastąpiło 25 grudnia po objęciu dowództwa przez arcyksięcia Karola - patrz: A. Manfred, op. cit., s. 382.

${ }^{65}$ A. Thiers, op. cit., s. 108-109.

${ }^{66}$ Cyt. z A. Thiers, op. cit., s. 109. 
Mimo zawieszenia broni w Steyr, Republika stale odnosiła zwycięstwa. Działania zbrojne zawieszone zostały bowiem tylko na froncie niemieckim, we Włoszech zaś, francuskie wojska posuwały się do przodu. 26 grudnia Guillaume Brune pokonał Austriaków nad Mincio, niedaleko Monzebano, 3 stycznia sforsował linię Adygi. 15 stycznia podpisał z Austriakami zawieszenie broni w Treviso, $25 \mathrm{~km}$ na północ od Wenecji ${ }^{67}$.

21 stycznia pierwszy konsul w liście do swojego brata, pełnomocnika w Lunéville, nakreślił konkretne instrukcje rozmów z Cobenzlem. Zapewniwszy go o wrogości Rosji wobec Anglii, przedstawił mu wytyczne w dziewięciu punktach. Co do wielkiego księcia Toskanii, miał on otrzymać, za poręczeniem Francji i Hiszpanii, proporcjonalne do swoich strat na Półwyspie tereny w Niemczech, przy czym dotychczasowe jego posiadłości miał objąć we władanie infant hiszpański. Aspekt ten, jednak miał zostać rozwinięty w odrębnym pokoju z Cesarstwem. Szwajcaria miała pozostać krajem niezależnym i neutralnym, Republika Cisalpińska miała uzyskać ustrój, który nie spowoduje „niepokojów w sąsiednich państwach”. Ostateczny traktat miał zostać podpisany jednak nie prędzej niż do dziesięciu dni ${ }^{68}$.

Po zajęciu przez generała Brune’a Wenecji i podpisania rozejmu, północne Włochy stanowiły kolejny equivalent. Zasługi głównodowodzącego armii Italii zostały całkowicie przysłonięte zwycięstwami spod Marengo i Hohenlinden. Polityka francuska do tego stopnia zaostrzała się w stosunku do Austrii, że Brune otrzymał rozkaz drastycznego podniesienia kontrybucji w krajach, które odstąpione miały zostać na podstawie pertraktowanego traktatu pokojowego. Celem zagrabienia jak największej ilości pieniędzy nie tylko było opłacenie żołnierzy francuskich, ale również postawienie Wiednia w trudnej sytuacji ${ }^{69}$.

9 lutego/20 pluviôse’a 1801 r. Republika Francuska osiągnęła kolejny sukces. Podpisany został pokój w Lunéville. Granicą pomiędzy Francją i Niemcami miał być zwyczajowo Ren. Książęta, których posiadłości zostały nadszarpnięte na lewym jego brzegu, mieli otrzymać rekompensatę. Miasta Dusseldorf, Ehrenbreitstein, Cassel, Kehl, Philipsburg i Breisach zostawały w granicach Niemiec, jednak ich fortyfikacje zostały zburzone. Przynależność prowincji belgijskich, hrabstwa Falkenstein, Fricktal, ziemie między Zurzach i Bazyleą do Francji została potwierdzona. Ponownie również uznano Lombardię za posiadłość Republiki Cisalpińskiej. Toskania przekazana została księciu Parmy w zamian za wynagrodzenie w Niemczech, zaś księciu Modeny obiecano Bryzgowię. Jedynym wynagrodzeniem domu habsburskiego były tereny Veneto aż po Adygę we Włoszech. Pokój miał być

${ }^{67}$ J.-P. Bertaud, op. cit., s. 34-35.

${ }^{68}$ Correspondance de Napoleon $I^{\text {er }}$, t. 6, $\mathrm{n}^{\circ}$ 5315, s. 738-740.

${ }^{69}$ Ibidem, $\mathrm{n}^{\circ} 5357$, s. 19-20. 
wspólny dla Republiki Francuskiej, Batawskiej, Helweckiej, Cisalpińskiej i Liguryjskiej, gwarantując równocześnie niepodległość czterem ostatnim. Obie strony zobowiązały się do wymiany ratyfikacji traktatu w ciągu $30 \mathrm{dni}$ od jego podpisania. Wojska francuskie zaś miały opuścić tereny Niemiec dopiero po wymianie, lecz ze zwłoką nie większą niż trzydziestodniowa. Nadmieniona została również gwarancja wolności dla więźniów politycznych, tu uwzględniono nazwiska Moscatiego i Caprary ${ }^{70}$.

Co wydaje się oczywiste, traktat w Lunéville znacznie bardziej uderzył w Habsburgów niż ten sprzed czterech lat z Campo Formio. Nie dosyć, że odebrano im Toskanię, to uzależniono od Francji Piemont - najważniejszego sojusznika austriackiego we Włoszech. Pomijając kwestie terytorialne, podkreślić należy, że zawarcie pokoju kontynentalnego z Austrią było jednym z dwóch najważniejszych celów, postawionych sobie przez pierwszego konsula. Na kontynencie działania zbrojne miały zostać więc wstrzymane.

Sytuacja była dla Republiki Francuskiej niezwykle korzystna. Duża większość krajów europejskich była jej sojusznikami, zaś najpoważniejszy wróg na kontynencie został właśnie zmuszony do podpisania pokoju. Ta koniunktura polityczna została jednak przerwana 11/23 marca, kiedy to zamordowany został imperator Paweł. Kolejnym ciosem dla Francji było zbombardowanie przez flotę angielską Kopenhagi. W sierpniu wojska francuskie zaś zostały zmuszone do kapitulacji Egiptu. W związku z tymi okolicznościami całkowite pokonanie Anglii okazało się niemożliwe. Wojnę z II koalicją zakończył pokój, podpisany w Amiens w marcu 1802 r.

Łatwo można zauważyć, że polityka austriacka względem Francji silnie była zależna od Rosji. Nie tylko bilans klęsk i zwycięstw potwierdza tę tezę, ale również fakt, że Austria zdecydowała się ponownie wystąpić ponownie przeciwko Francji dopiero w 1805 r. u boku Rosji. Wojna ta zakończyła się klęską i rozpadem Świętego Cesarstwa Rzymskiego. Równocześnie dostrzegamy w omawianych dziejach niezwykle istotną rolę pieniędzy angielskich. Londyn bowiem konsekwentnie prowadził politykę walki do ostatniej kropli krwi - swoich sojuszników. Strumienie angielskiego złota nie tylko wówczas podburzały włoską ludność przeciwko Francji, utrzymywały Austrię w stanie wojny, ale doprowadziły do zamordowania cara.

Przyczyną ciągnących się konfliktów pomiędzy głównymi mocarstwami europejskimi były również marionetkowe, ale niezwykle bogate Włochy. Rozdrobnienie polityczne półwyspu Apenińskiego osłabiało go wewnętrznie i czyniło go obszarem walk o strefę wpływów. Italia stanowiła miejsce konfliktów od średniowiecza aż do drugiej połowy XIX wieku, angażując przede wszystkim Francję i Austrię.

${ }^{70}$ A. Thiers, op. cit., s. $116-118$. 


\section{BIBLIOGRAFIA}

\section{Źródła}

Almanach national de France, l'anhuitième de la République Françoise une et indivisible, Paryż 1799.

Correspondance de Napoléon I ${ }^{\text {er }}$, t. 1-7, Paris 1858-1861.

Correspondance de Talleyrand avec le Premier Consul pendant la campagne de Marengo, publiée par Le $C^{\text {te }}$ Boulay de la Meurthe, [bmw] 1892.

De Las Cases E., Memoriał ze św. Heleny, t. 3, Gdańsk 2012.

Дипломатические сношения России с Францией в эпоху Наполеона, t. I, wyd. A.S. Traczewski, Сборник Императорского Русского Исторического Общества, t. 70, Sankt Petersburg 1890.

Iung Th., Lucien Bonaparte et sesmémoires 1775-1840, t. 2, Paris 1882.

Lettres inédites de Talleyrand a Napoléon 1800-1809 publiées d'après les orginaux conservés aux archives des Affaires étrangères avec une introduction et des notes par Pierre Bertrand, Paris 1889.

Mémoires du prince de Talleyrand, publiés avec uneprace et des notes par le duc de Brogile de l'Académie Française, t. 1, Paris 1891.

Thiers A., Historia Konsulatu i Cesarstwa, t. 1, tłum. L. Rogalski, Oświęcim 2013-2014.

\section{Opracowania}

Baszkiewicz J., Anatomia bonapartyzmu, Gdańsk 2003.

Baszkiewicz J., Historia Francji, Wrocław 1978.

Bazylow L., Historia Rosji, t. 1, Warszawa 1983.

Bertaud J.-P., Histoire du Consulat et de l'Empire. Chronologie commentée, Paris 2004.

Bielecki R., Napoleon, Warszawa 1979.

Calendier Napoléon présentant puor chaque jour de l'année une époque mémorable de la vie de Napoléon - Bonaparte, deupis sa naissance jusqu'a sa mort, chez Charles Painparré, Paris 1821.

Ejdelman N., Paweł I, czyli śmierć tyrana, Warszawa 1990.

Gierowski J.A., Historia Włoch, Wrocław 2003.

Godechot J., L'Europe et l'Amerique a l'époque napoléonienne (1800-1815), Paris 1967.

Greppi G., Sardigne, Autriche-Russie pendant la première et la duxième coalition (1796-1802), Rome 1910.

Harris R., Talleyrand, Warszawa 2008.

Histoire de France, depuis le 18 brumaire (novembre 1799) jusqu'a la paix de Tilsitt (juillet 1807), par M. Bignon, t. 1, Paris 1829.

Histoire de la politique des puissances de l'Europe, depuis le commencement de la Révolution Française jusqu'a congrès de Vienne, par M. le Comte de Paoli-Chagny, t. 1, Paris 1817. 
Lovie J, Palluel-Guillard A., L'épisode napoléonien. Aspect sextérieurs (1789-1815), Paris 1972. Manfred A., Napoleon Bonaparte, t. 1, Warszawa 1986.

Orieux J., Talleyrand, Warszawa 1989.

Razumovsky M., Razumowscy: rodzina na carskim dworze 1730-1815, Warszawa 2005.

Roberts A., Napoleon Wielki, wersja elektroniczna 2015.

Sorel A., l'Europe et la révolution française, Paris 1903.

Tarle E., Napoleon, Warszawa 1967.

Tersen E., Napoléon, Paris 1968.

The Cambridge History of British Foreign Policy 1783-1919, t. 1, red. A.W. Ward i G.P. Gooch, Cambridge 1922.

Tulard J., Napoleon - mit zbawcy, Warszawa 2003.

Wendruszka A., Das Haus Habsburg - die Geschichte einer europäischen Dynastie, Stuttgart 1956.

Wereszycki H., Historia Austrii, Wrocław 1986.

Zahorski A., Napoleon, Warszawa 1982.

Zins H., Historia Anglii, Wrocław 1971.

Żywczyński M., Włochy nowożytne 1796-1945, Warszawa 1971.

Michat Balogh

\title{
FRENCH-AUSTRIAN POLITIC RELATIONS SINCE BATTLE OF MARENGO TILL PEACE TREATY OF LUNÉVILLE
}

\begin{abstract}
A prer près la campagne de 1797 et le traité de Campo Formio, l'Autriche subit des pertes: elle perdit principalement la rivegauche du Rhin, la Lombardie et les provinces belges. En l'an 1798 l'empereur Paul Ier decida de sejoindre au conflit. Il donna l'espoire à l'Angleterre et l'Autriche. La guerre commenca entre la France et ses alliés contre la deuxième coalition. Après de nombreuses victoires des enemis de la République, Paul, trompé par sesalliés, decida de changer de camp. La bataille de Marengo changea la situation. L'Autricheéchoua et a dûessayer de signer la paixcontinentale. L'Angleterresoutint Vienne en versantunesomme de 2,5 mln de livres, mais imposaune conditio: que le gouvernement autrichienne fasse pas la paix séparé avec la France jusqu'àfévrier 1801. Délégué à Paris Saint-Julien signales préliminaires, bienqu'iln'avait pas de pouvoirs. Le prolongement de l'armisticecoûta à l'Autriche la fortresse de Inglostadt, Ulm i Philippsburg. La discussion officielle entre Joseph Bonaparte et Jean Cobenzl commenca en Octobre. Le résultat fût le traité de paix de Lunéville signé le 9 février 1801, qui mit fin à la guerre continentale.
\end{abstract}

Keywords: Napoleon, France, foreign policy, Bonaparte, Marengo, Lunéville. 